\title{
The development of vowel harmony in Proto-Uralic and Proto-Finno-Ugrian
}

1. In my article entitled "A magánhangzó-harmónia egyes típusai (Various Types of Vowel Harmony)" (1976: 417 - 424, in German 1977: 167 174) I differentiated the following types of vowel harmony on the basis of the oppositions arising from the distinctive features of the vowels: 1) palato-velar or palatal harmony, 2) labial harmony, 3) harmony according to grade of aperture. The attribute "various" in the title of my article points to the fact that vowel harmony can have even more variants; in my article I restricted myself, however, to the discussion of those mentioned above. Strictly speaking, vowel harmony is a form of assimilation; thus its types can be differentiated according to the horizontal and vertical movements of the tongue. In the same issue of our journal István Bátori addresses himself to the question of why there is no vowel harmony in Lapp (273 - 283). In a note at the foot of page 278 he makes reference to an earlier article of mine (1969: 130 - 141, see also 1968: 35 - 45) in which I discuss the lines of development of the vowels of the first syllable in the Permian languages and in which I attempt to explain certain historical phonological processes with the assimilating influence of the FU-FP vowels of the non-initial syllable ( $a$, $\ddot{a}, e)$, with vowel harmony according to grade of aperture. My purpose was, therefore, not the analysis of vowel harmony (or of vowel harmony types); I only touched upon this question in connection with the historical phonological phenomena under discussion. Bátori (1976: 278 note) draws the conclusion that I wish to use the technical term "vowel harmony" in a wider sense of the word. This is quite true, but as will be shown below, I do not stand alone with this opinion. Bátori regards vowel harmony as being only palato-velar or palatal harmony as well as labial assimilation. Vowel harmony according to grade of aperture belongs in his consideration to the sphere of umlaut. In its original form, umlaut means the regressive, assimilating 
influence of $i$ and $e$ in non-initial syllables on the vowel of the first syllable in the Germanic languages (e.g. German Baum Bäume, Gast Gäste, Stuhl Stühle). I have not revised my opinion that umlaut - or metaphony - is in the wider sense of the word a type of vowel harmony, for we are dealing here with nothing else but the regressive assimilating influence of the vowels in non-initial syllables on the vowel of the first syllable. In Lapp, due to the influence of $* a, * a,{ }^{*} e$ in non-initial syllables, the vowel of the preceding syllable became lower or higher. E.g:

e-ä > æ-ä: Finn. pesä Lapp N bæsse 'nest'

o-a > oa-a: Finn. kota Lapp N goatte 'tent'

ä-e > (e)ie-e: Finn. käte- Lapp N giettâ 'hand'

a-e > (olvo-e: Finn. appe- Lapp N vuop'pâ 'son-in-law'

The Lapp umlaut phenomena cited by Bátori were discovered long ago. Genetz (p. 52): "toisen tavuun vokaali on antisipeerattu ensi tavuusen, nim. $\varepsilon$-vartaloissa alkuperäisen vokaalin eteen ja $\alpha(\omega)$-vartaloissa sen jälkeen". E. Itkonen (1939: 56 - 75) calls the raising or lowering of the vowel resulting from the influence of the second syllable regressive vowel harmony. If we then regard all the vowel assimilations according to the above mentioned horizontal and vertical tongue movements as being vowel harmony, then the vowel changes in question, i.e. those having taken place in the Lapp firstsyllable vowel system - we can call this phenomenon umlaut, metaphony, or regressive vowel harmony - by stricter definition fall under the category of vowel harmony according to grade of aperture. In addition, Bátori, with his narrow interpretation of vowel harmony - restricting it merely to palatovelar harmony and labial assimilation - stands quite alone. In addition to myself, others, too, have distinguished various forms of vowel harmony (Trubetzkoy 93, 100, 259; Clements 1977: 111 - 119; Ringen 1979: 247 259).

In a later article, Bátori (1984) would seem to recognize several variants belonging to vowel harmony. At least, his classification of vowel assimilations into four types according to the horizontal and vertical movements of the tongue would seem to point in this direction. From the title of the study, however [Vokalharmonie und Inverse im Lappischen (Vowel Harmony and Inversion in Lapp)] and from his method of discussion it becomes clear that the author sets vowel harmony (= palato-velar harmony) 
apart from the other variants, which in my opinion fall under this category. Also in this article - and with this we are in full agreement - he connects the umlaut with the disappearance of palato-velar harmony in Lapp.

In his article entitled "Die Vokalharmonie in den finnisch-ugrischen Sprachen und ihre Rekonstruktion für die Ursprache (Vowel Harmony in the Finno-Ugrian Languages and its Reconstruction for the Proto-Language)" (1982) Bátori discusses the various forms taken by palato-velar vowel harmony in the Finno-Ugrian languages. (For the most part, generally wellknown facts are treated.) He touches upon the reasons for the disappearance of vowel harmony in the various languages and sees these reasons in the following processes:

1. Row change on the part of the individual vowels

2. Spread in palatal attraction

3. Vowel harmony giving way to umlaut

On pages 164 and 165 of his work he lists the criteria for the reconstruction of vowel harmony for the proto-language. As regards the forces working against palato-velar vowel harmony, our results - with a different method of approach - agree in numerous points (see Rédei 1976: 417 - 424, 1977: 167 - 174). In the place of row change on the part of the individual vowels, I speak of vowel change: the dissolution of vowel harmony is in many cases connected with the velarization of an originally palatal vowel (in the case of double suffixes, that containing the velar vowel was generalized) (1. c. 429) ${ }^{1}$. Instead of "palatal attraction" I use the term "synharmony" (Rédei 1976: 422, 1977: 172, 1982: 176, see also Trubetzkoy 251). The giving way of palato-velar harmony in many cases to umlaut corresponds in my writings to vowel harmony according to grade of aperture. ${ }^{2}$

2. The purpose of my present article is to discuss to which extent vowel harmony can be presumed to have existed in Proto-Uralian or Proto-FinnoUgrian and, if it did exist, to which extent it was productive. Researchers nowadays are generally in agreement that the proto-language had vowel harmony and that as regards its type it was a palato-velar or more briefly, a palatal vowel harmony. The existence of vowel harmony can/may to a certain degree be connected with the agglutinative character of the protolanguage, although there is no lack of agglutinative languages without vowel harmony (Northern Vogul, Northern Ostyak, Zyrian, Votyak, Japanese, 
Malay, etc.) (cf. Rédei 1976: 419, 1977: 169). One function of vowel harmony in agglutinating languages can be seen as the effort to make the word as a whole (stem + derivational suffix + base suffix + inflectional suffix) form a phonological-morphological unity. Vowel harmony acts then as a boundary marker, at the same time, the morphonological boundary between the various morphemes - as a result of the transparent character of agglutination - does not become obscured. Thus, strongly agglutinative languages with vowel harmony are less exposed to ablaut-like changes in the word stem and to morphonological changes resulting in the obscuring of the morpheme boundary when morphemes are joined.

On the basis of the vowel harmony systems existing in the present-day languages, the vowel harmony which can be reconstructed for the protolanguage had the following criteria (with regard to these criteria see Rédei 1976: 417 -, 1977: 167 -; Bátori 1982: 154 - 155, 164 - 165):

1. Radical harmony (stem harmony).

2. Suffixal harmony (existence of parallel endings).

3. The vowel harmony was based on the palatal-velar opposition.

4. As regards the direction of vowel harmony in the proto-language, it is likely to have been progressive.

5. The assimilative adjustment was valid for the entire word. (Thus we cannot speak of syllabic synharmony such as it for example appears as a more recent phenomenon in certain Finno-Ugrian languages, nor as in certain disharmonic loan-words of the Turkish language.) ${ }^{3}$

6. The class of neutral vowels $(i, e)$.

In order to be able to clarify the conditions for the functioning of this system it is above all of importance to note that palato-velar vowel harmony has two subtypes: 1) radical or stem harmony, and 2) suffixal harmony. Radical vowel harmony merely comprises the taxonomic rules of vowel combinations. A system of vowel combinations can be therefore a prerequisite for the origination of vowel harmony, or for its functioning, but we can truly speak of vowel harmony only in the case of the existence of suffixal harmony. E. Itkonen is therefore right (1961: 64 -) when he traces the origination of vowel harmony back to combinational possibilities. "All the vowels of Proto-Finno-Ugrian ( $u, 0, a, i, \ddot{u}, e, a ̈)$ could be present in the stressed first syllable of a word; in the non-stressed second syllable, however, only $a$, $\ddot{a}$, e could occur. Thus, in the first syllable the following vowel oppositions 
occurred: $a-a ̈, o-e, u-\ddot{u}$ and the unmatched $i$; in the second syllable there was the oppositional pair $a-a ̈$ and the unmatched $e$. It is then completely natural that the back vowels of the first syllable were combined with the a of the second syllable, the front vowels, on the other hand, with the $\ddot{a}$ of the second syllable. The unmatched $i$ could be combined with $\ddot{a}$ as well as with $a$ (cf. Finn. silmä 'eye', Ilma 'air'); the e of the second syllable could be combined with any vowel of the first syllable (cf. Finn. väke- 'strength, power; people', teke- 'to do' sylke- 'to spit; saliva', nime- 'name', pane- 'to put', poske- 'cheek', kulke- 'to go, wander'). On the basis of this combination theory it can be assumed that as regards vowel harmony, $e$ and $i$ could have been neutral vowels in the Finno-Ugrian period, too. Accordingly, the present-day disharmonic words of the Finnish and Hungarian languages are representative of old types." (Rédei 1976: 418 - 419, 1977: 168 - 169.) As regards radical vowel harmony in the proto-language see also Sammallahti 1979: 60 - 61, 1980: 3 - 7, Janhunen 1981: 220, 1982: 26 - 27.

Regarding the combination of word stems and endings we are dealing with progressive assimilation in the proto-language as well as in the present-day Finno-Ugrian languages possessing vowel harmony. The progressive assimilation of the vowel of the endings attached to palatal or velar stems implicated, therefore, the origination of vowel harmony. Let it be noted that with the retrogression of vowel harmony we can observe the retention to a greater or lesser degree of radical harmony (vowel combination) but the dissolution of the assimilation rule for the suffixes (MokšaMordvin, Eastern Cheremis - here only labial assimilation). Another factor pointing to the primary importance of the productivity of suffixal harmony is that whereas there are numerous exceptions to radical harmony (disharmonic words, the elements of compound words do not assimilate according to the rules of vowel harmony), a much smaller degree of irregularity is to be observed in the suffixes. The number of double palato-velar suffixes is in the case of the productivity of vowel harmony quite large, the number of single-form endings containing a neutral vowel is, on the other hand, relatively small (e.g. Hung.: -ig, -ik, -ért, -ként etc., Finn.: -lle, -ksi, $-k s e,-m m e,-n n e$, etc.).

3. Let us examine from the point of view of the functioning of vowel harmony in the proto-language the participation of the reconstructable suf- 
fixes (derivational suffixes, base suffixes, inflectional suffixes) in vowel harmony. As is known, only the following three vowels occurred in noninitial syllables in the proto-language: $a, \ddot{a}$, e. Suffixal vowel harmony could, of course, only occur in the case of those suffixes containing the vowels $a$, ä. As regards the derivational suffixes, we are faced with two difficulties:

1. It is not always possible to determine the precise vowel of a derivational suffix.

2. Through word derivation - as we know - a new word stem (base) is formed and thus the connection stem + derivational suffix in point of fact results in a static state, i.e. the derived word represents a lesser degree of productivity from the point of view of vowel harmony. In any case, it is apparent that in the case of double suffixes, the "selection" of the derivational suffix to be attached to the stem took place in accordance with palato-velar harmony. A goodly number of such double derivational suffixes can be reconstructed for the protolanguage. E.g.: *-ja *-jä, *-ma *-mä, *-na *-nä, *-pa *-pä, etc.

In the examination of the functioning of suffixal vowel harmony in the proto-language it is above all the base suffixes and inflectional suffixes which must be taken into account. The numeral suffixes $\left(*^{*}, *^{*} n, *_{i}<*_{j}\right.$, perhaps *k) were single-form suffixes (cf. Collinder 235 - 238, 297 - 302; Hajdú 1966: 67 - 68, 128 - 130; Rédei 1981a: 97 - 105, 1981b: 210 - 219), thus having no part in vowel harmony. The agglutination of the personal pronouns (*me, ${ }^{*} t e,{ }^{*} s e$ or $\left.{ }^{*} m_{3},{ }^{*} t_{3},{ }^{*} s_{3}\right)$ to nominal stems (in the case of possessive personal suffixes) had already taken place in the proto-language. The personal pronouns - inasmuch as they contained a neutral $e$ - were indifferent with regard to suffixal vowel harmony in the proto-language. A lack of vowel harmony must also be assumed for the case that $e$ disappeared as early as the proto-language as a result of dynamic first-syllable stress. It is, of course, also conceivable that the personal pronouns were originally enclitical elements marking the personal spheres, and thus assimilated to the word preceding or following them according to the rules of vowel harmony. An indication for this can be seen in the fact that the personal pronouns in several languages have not palatal, but velar continuations (Mordvin, Lappish). Further proof for the old enclitic character of the personal pronouns can be found in their syntactic position, in that the personal 
pronouns followed the modified word in an attributive role (in the possessive personal marking), and followed the verb in the function of an active subject. To sum up: judging from their original enclitic character, the personal pronouns could end not only in e, but also in a and $\ddot{a}$. In the latter case they had of necessity to take part in suffixal vowel harmony.

As the tense and mood markers (past tense $*_{i}<* j$, ${ }^{*}$, conditional mood *ne) possessed only single forms, they were not suited to take part in suffixal vowel harmony.

For the PU-PFU proto-language the existence of the following case suffixes can be presumed (Collinder 238 - 241; Hajdú 1966: 62 - 67, 118 - 127; Rédei 1975: 133):

1. Nom. $\emptyset$

2. Acc. ${ }^{*}-m$

3. Gen. *-n

4. Loc. I *-na/*-nä

5. Loc. II (PFU) *-t, *-tt3

6. Abl. *-ta/*-tä

7. Lat.-Prol. $1 *-k$

8. Lat.-Prol. II (PFU) *-j

9. Lat.-Dat. III *-ń

As can be seen, several case suffixes ended in a consonant. These, then, cannot be taken into consideration from the point of view of suffixal vowel harmony. In one case (loc. *-t, *-tt3), the possible final vowel cannot be determined. Actually, it is only in the case of the locative *-na/-*nä and the ablative *-ta/*-tä that we can assume the existence of double suffixes, that they took a productive part in suffixal vowel harmony as early as in the proto-language is evident. Of course, the locative *-tt3 can in principle be traced back to double forms with a/ä, but it is also possible that the final vowel of the suffix was $e$.

From the reconstructable suffixes the conclusion can be drawn that the number of bound morphemes capable of playing a role in the functioning of vowel harmony in the proto-language was quite small. In the proto-language there was probably a goodly number of double derivational suffixes ending in a/ä. These, however, - as shown above - had less importance from the point of view of the functioning of vowel harmony. The possessive personal suf- 
fixes and verbal personal suffixes originating from personal pronouns could only take part in vowèl harmony if their vowel element was, also, a/ä and if the apocope had not already taken place. In summary: apart from the derivational suffixes ending in $a / \ddot{a}$ only the locative ${ }^{*}-n a /^{*}-n a ̈$ and the ablative *-ta/*-tä indicate that suffixal vowel harmony - if only in embryo form was already in existence at the time of the proto-language.

4. Which factors could have led to the origination of palato-velar vowel harmony and to its complete formation and development? For the development of vowel harmony the vowel combination rules of the word stems played a major role. As we know, the velar or palatal vowel of the first syllable determined which vowel could occur in the second syllable. This is still characteristic of several Finno-Ugrian languages. As regards the combinational possibilities, $i$ in the first syllable as well as $e$ in non-initial syllables were neutral vowels. The existence of radical vowel harmony or vowel combinations, the stressing of the first syllable together with the presumably restricted agglutinative character of the proto-language - these were the factors which - as if it were programmed in advence - led to the development of suffixal vowel harmony.

Although we do not know the linking rules for the morphemes of the proto-language, nor the morphonological changes possibly occurring at the morpheme boundary, the limited number of bound morphemes and the frequent homonymity shown by them are characteristics which indicate that the proto-language was to a lesser degree an agglutinative language type than the various present-day Finno-Ugrian languages. "In the light of its case system it would appear that the Uralic proto-language can be traced back to a less agglutinative language form. In the form shown by the reconstructions, the Uralic proto-language contains a high degree of homonymity of the grammatical morphemes. Let it be remembered how many different functions the suffixes ${ }^{*} n, j$, and $* k$ had. In addition, there was a synonymity of morphemes, i.e. several morphemes had the same function, e.g. plural $*_{-} t, *^{*},{ }^{*}-n$, and $-k$ as well as lative $*_{-} n, *^{*}$, and $*_{-} k$. These characteristics, as well as the vowel alternation only sparsely documented (e.g. Finn. palaa 'to burn, itr.' - polttaa 'to burn, tr.', Hung. hal 'to die' holt 'dead') can be taken as a sign of a pre-Uralic flectional language form." (Korhonen 1979: 17.) 
The circumstance that suffixal vowel harmony in all probability extended to only a very small number of endings also speaks for the restricted agglutinative character of the proto-language. Today in the languages with vowel harmony - above all in Hungarian and Finnish - there is an abundance of palato-velar word pairs: Hung. dörren 'to thunder, rumble' durran 'to bang, crack', kever 'to mix, stir' kavar 'to stir, beat'; Finn. kihinä 'hissing noise, fizz' kohina 'rush, swish, roar', kilistä 'to tinkle, jingle, clink' kolista 'to rattle, clatter'. Such word pairs can only in one or two cases be traced back to the proto-language (see e.g. the entries in MSzFgrE fekély 'ulcer, abscess', fakad 'to spring, flow, pour' and far 'but tock(s), posterior'). The lack of word pairs of this type could also be indicative of the lesser productivity of vowel harmony in the proto-language.

The final development of suffixal vowel harmony took place in the course of evolution of the individual Finno-Ugrian languages and is without doubt connected with the ever increasing agglutinative nature of these languages, here particularly with the origination of double endings (inflectional suffixes, derivational suffixes). ${ }^{4}$

KÁROL Y RÉDEI

\section{FOOTNOTES}

1. The following question is worthy of examination. When vowel harmony dissolves, why is it that of the variants the one with a velar vowel becomes general in most cases? As regards the coinciding $a / \ddot{a}>a$, this could perhaps be explained by the fact that there are many vowel systems in existence without an $\ddot{a}$, but on the other hand a vowel system lacking an a can hardly be imagined. (Trubetzkoy $86-114$, see also Steinitz 184.)

2. I might also mention that in the Finnish examples cited by Bátori various mistakes - regrettably - occur. E.g.: 1981: 37 keitiö (O: keittiö), liito (O: liitto), 1982: 155 tyhjen-tä-mä-ttö-myy-kse-ssä (つ: tyhjen-tä-mä-ttömyy-de-ssä), tahdo-too-muu-kse-ssa-nsa ( 0 : tahdo-tto-muu-de-ssa-nsa), 1984: 297 operetti-ssa (J : opereti-ssa).

3. It can be assumed that velar suffixes were attached to disharmonic words, just as for example in modern Finnish: ilma ilmassa 'in the air', tule- tulessa 'in the fire'. The fluctuation typical of Hungarian (nyíl 
nyillal 'with the arrow', híd hídon 'on the bridge', kocsi - kocsiban 'in the car', dëszka dëszkával 'with the board', októbër októbërben 'in Oçtober', oxigén oxigénnal oxigénnel 'with oxygen', Ágnës Ágnësnek Ágnësnak 'to Agnes') is of apparently late origin (as regards the disharmonic words see Rédei 1976: 418, 1977: 168, Ringen 1978: 105 - 115, 1980: 9 - 18). The disharmonic words containing $i$ belong to the old word stock of the Hungarian language: they are of FU origin or are very old loan-words (such as e.g. híd < Alanic). Proof for the more recent origination of disharmonic words with $e$ is also the fact that there are singleform suffixes with $i$ or $\hat{e}$ in Hungarian, but absolutely no single-form suffixes containing a neutral e. The assimilation of the type oxigennal, Agnësnak is perhaps not only typologically, but also genetically related to the Finnish type, i.e. the usage of velar suffixes with disharmonic words could well be the continuation of Finno-Ugrian assimilation. In contrast to this, the assimilation of the type oxigennel, Ágnësnek might possibly have arisen due to Turkish influence before Conquest (to the extent that the syllabic assimilation present in loan-words can be seen as being old in Turkic (Turkish hezar hezarda 'in thousand', pilot pilotlar 'the pilots', otomobil otomobiller 'the cars'). (As to the types of vowel harmony in Turkish see Turkologie 1963: 8 - 9, 34, 55 - 56, 63, 95 - 96, $140,163,177$ - 178.) In addition to the partial retention of vowel harmony, syllabic synharmony or, differently, palatal attraction also exists, e.g. in Erza-Mordvin (Rédei 1982: 176 - 177), in Veps (Suhonen 1980: 19 21) and in Southern Ostyak (Vértes 1977: passim, 1980: 27 - 39). In Yurak there is syllabic synharmony, but vowel harmony is unknown (Hajdú 1968: $29,33)$, although certain suffixes follow the rules of suffixal vowel harmony e.g.: nano-Xona 'in the boat', tü-Xuna 'in the fire', ni-Xina 'with the belt', tupka-Xana 'with the axe', nuda-Xad 'from the hand', te-Xed 'from the reindeer' (Collinder 208 - 209; Hajdú, op. cit. 32, 41 ).

4. At first, vowel harmony does not effect the newer (secondary) case suffixes. E.g.: HB halalnec (today: halalnak), HB iovben, milostben (today: joban, malasztban). The active influence of suffixal vowel harmony, however, brought about the formation of double suffixes here, too: -nak/-nek, -ban/-ben, etc.

\section{BIBLIOGRAPHY}

Bátori 1976 = Bátori, István, Miért nincs a lapp nyelvben magánhangzóharmónia? NyK 78: 273 - 283.

Bátori 1981 = Bátori, István, Die finnischugrische Vokalharmonie - ein Rekonstruktionsversuch. In: CQuilFU 6: 34 - 39. Turku.

Bátori 1982 = Bátori, István, Die Vokalharmonie in den finnischugrischen Sprachen und ihre Rekonstruktion für die Ursprache. Zeitschrift für Sprachwissenschaft 1: 151 - 170. Göttingen. 
Bátori 1984 = Bátori, István, Vokalharmonie und ihre Inverse im Lappischen. In: Studien zur phonologischen Beschreibung uralischer Sprachen [eds.: Hajdú, P. - Honti, L.]: 295 - 301 . Budapest.

Clements 1977 = Clements, George N., The Autosegmental Treatment of Vowel Harmony. In: Phonologica 1976. Akten der 3. Internationalen Phonologie-Tagung Wien [eds.: Dressler, W. U. - Pfeiffer, O. E.]: 111 119. Innsbruck.

Collinder = Collinder, Björn, Comparative Grammar of the Uralic Languages. Stockholm 1960.

Genetz = Genetz, Arvid, Ensi tavuun vokaalit suomen, lapin ja mordvan kaksi- ja useampitavuisissa sanoissa. Suomi 1897/3/13/3: 1 - 56.

Hajdú 1966 = Hajdú, Péter, Bevezetés az uráli nyelvtudományba. Budapest.

E. Itkonen 1939 = Itkonen, Erkki, Der ostlappische Vokalismus vom qualitativen Standpunkt aus. MSFOu 79. Helsinki.

E. Itkonen 1961 = Itkonen, Erkki, Suomalais-ugrilaisen kielen- ja historiantutkimuksen alalta. Tietolipas 20. Helsinki.

Janhunen 1981 = Janhunen, Juha, Uralilaisen kantakielen sanastoa. JSFOu 77: $219-274$.

Janhunen 1982 = Janhunen, Juha, On the structure of Proto-Uralic. FUF 44: $23-42$.

Korhonen 1979 = Korhonen, Mikko, Entwicklungstendenzen des finnischugrischen Kasussystems. FUF 43: 1 - 21.

Rédei 1968 = Rédei, Károly, A permi nyelvek elsó szótagi magánhangzóinak a tör ténetéhez. NyK 70: $35-45$.

Rédei 1969 = Rédei, Károly, Neue Aspekte zur permischen Vokalforschung. UAJb $130-141$.

Rédei 1975 = Rédei, Károly, Der Akkusativ in den uralischen Sprachen (Zum Kasussystem der uralischen Sprachen). In: CTIFU 1: 133 - 138. Tallinn.

Rédei 1976 = Rédei, Károly, A magánhangzó-harmónia egyes típusai. NyK 78: $417-424$.

Rédei 1977 = Rédei, Károly, Einige Typen der Vokalharmonie. In: Phonologica 1976. Akten der dritten Internationalen Phonologie-Tagung Wien [eds.: Dressler, W. U. - Pfeiffer, O. E.]: 167 - 174. Innsbruck.

Rédei 1981a = Rédei, Károly, Többesjelek a PU-PFU alapnyelvben. NyK 83: $97-105$. 
Rédei $1981 \mathrm{~b}=$ Rédei, Károly, Monikon tunnukset uralilaisessa ja suomalaisugrilaisessa kantakielessä. In: CQuiIFU 6: 210 - 219. Turku.

Rédei 1982 = Rédei, Károly, Beitrag zur Vokalharmonie im Ersa-Mordwinischen. SFU 18: $176-177$.

Ringen 1978 = Ringen, Catherine O., Another view of the Theoretical Implications of Hungarian Vowel Harmony. Linguistic Inquiry 9/1: 105-115.

Ringen 1979 = Ringen, Catherine O., Vowel Harmony in Igbo and DiolaFogny. Studies in African Linguistics 10: $247-259$.

Ringen $1980=$ Ringen, Catherine O., Vowel Harmony in Finnish and Hungarian. In: CQuilFU 3: 9 - 18. Turku.

Sammallahti 1979 = Sammallahti, Pekka, Uber die Laut- und Morphemstruktur der uralischen Grundsprache. FUF 43: 22 - 66.

Sammallahti 1980 = Sammallahti, Pekka, Introduction to the Round-Table Session "Vowel Harmony". In: CQuilFU 3: 3 - 7. Turku.

Steinitz = Steinitz, Wolfgang, Geschichte des wogulischen Vokalismus. Berlin 1955.

Suhonen 1980 = Suhonen, Seppo, Uber die Typen der Vokalharmonie in den ostseefinnischen Sprachen. In: CQuilFU 3: 19 - 25. Turku.

Trubetzkoy = Trubetzkoy, N. S., Grundzüge der Phonologie ${ }^{5}$. Göttingen 1971.

Turkologie 1963 = Handbuch der Orientalistik [ed.: Spuler, B.]. Fünfter Band Altaistik. Erster Abschnitt Turkologie. Leiden-Köln.

Vértes 1977 = Vértes, Edit, Morphonematische Untersuchung der ostjakischen Vokalharmonie. Budapest.

Vértes 1980 = Vértes, Edit, Konsonantenstatistik und Vokalharmonie im Südostjakischen. In: CQuilFU 3: 27 - 39. Turku. 